\title{
Hal 1-17
}

\section{REKAYASA TEKNOLOGI PENGOLAHAN IKAN TEMBANG (Sardinella Sp) MENJADI BEBERAPA PRODUK KOMERSIL DALAM RANGKA MENINGKATKAN NILAI JUAL PRODUK PERIKANAN}

\author{
(Engineering Technology of Tembang Fish (Sardinella Sp) Processing To Be Some \\ Commercial Products In Order To Improve The Value Of Selling \\ Fisheries Products) \\ oleh: \\ Amrah Husma ${ }^{1}$, Muhammad Khidri Alwi ${ }^{2}$, Winarno Arifin ${ }^{3)}$ \\ 1) Program Studi Budidaya Perairan FPIK UMI \\ 2) Program Studi Kesehatan Masyarakat, FKM UMI \\ ${ }^{3)}$ Program Studi Teknik Sipil FT UMI
}

Korespondensi: amrah.husna@umi.ac.id

Diterima: tanggal 2 Februari 2019; Disetujui 15 Mei 2019

\begin{abstract}
The optimum effort effort in fishing activities and the actual level of utilization of tembang fish resources in the Makassar Strait waters are increasing every day. Based on the reality conditions above, in order to increase the selling value of tembang fish to further increase the income of fishermen, engineering research on tembang fish processing technology is needed into several commercial products with more modern processing methods and can be stored in a relatively long time and sell well on standard markets. national and international. The purpose of this study was to find out how the practical method of processing tembang fish into canned fish, fish sauce and fish silage, is a standard home industry that has high economic value and relatively long lasting power. The urgency of this study is expected to be a basic knowledge of the community in order to increase the selling value of tembang fish as a fishery product with high economic value that can improve the standard of living of the community.The processing method carried out is a combination of traditional methods and modern methods, including methods of cooking, fermentation, salting, enzyme use, sterilization, and packaging systems to produce processed products that are of high quality and have high selling value. Data analysis to be carried out for quantitative data is analysis of variance (complete randomized design) and for qualitative data observed by organoleptic test and processed by descriptive method. Processed products produced in this study are fish sauce, canned fish and fish silage.
\end{abstract}

Keywords: Tembang Fish, Canned Fish, Fish Soy Sauce, Fish Selase, increase economic value

\section{ABSTRAK}

Upaya effort optimum dalam kegiatan penangkapan dan kondisi aktual tingkat pemanfaatan sumberdaya ikan tembang di perairan Selat Makasar semakin hari semakin meningkat. Berdasarkan realitas maka dibutuhkan penelitian rekayasa teknologi pengolahan ikan tembang menjadi beberapa produk komersil dengan metode pengolahan yang lebih moderen dan dapat disimpan dalam waktu yang relatif lama serta layak jual pada pasar bertaraf nasional dan internasional. Tujuan penelitian ini adalah untuk menemukanbagaimana metode praktis pengolahan ikan tembang menjadi Ikan kaleng, Kecap ikan dan Silase ikan, bertaraf home industri yang memiliki nilai ekonomi tinggi dan daya awet relatif lama.Urgensi penelitian ini diharapkan dapat menjadi pengetahuan dasar masyarakat dalam rangka meningkatkan nilai jual ikan tembang sebagai produk perikanan yang bernilai ekonomi tinggi yang dapat meningkatkan taraf hidup masyarakat. Metode pengolahan yang dilakukan adalah perpaduan antara metode tradisional dan metode modern, meliputi metode pemasakan, fermentasi, penggaraman, penggunaan enzim, sterilisasi, dan sistem pengemasan untuk menghasilkan produk olahan yang berkualitas dan memiliki nilai jual tinggi. Analisis data yang akan dilakukan untuk data kuantitatif adalah analisis sidik ragam (rancangan acak lengkap) dan untuk data kualitatif diamati dengan uji organoleptik dan diolah dengan metode diskriptif. Produk olahan yang dihasilkan dalam penelitian ini adalah Kecap ikan, Ikan kalengdan, silase ikan.

Kata Kunci: Ikan Tembang, Ikan Kaleng, Kecap Ikan, Selase Ikan, meningkatkan nilai ekonomi. 
PENDAHULUAN

Ikan Tembang (Sardinella sp) merupakan jenis ikan yang mudah mengalami pembusukan, bersisik diseluruh permukaan tubuhnya, bertulang banyak dankeras serta tidak memiliki daging yang banyak. Hal ini menyebabkan tidak banyak diminati dan dibeli oleh masyarakat sebagai bahan kebutuhan sehari-hari, oleh karena pengolahan dan pembersihannya cukup berat. Akibat kurang diminati oleh masyarakat sehingga nilai jual ikan tembang sangat rendah bahkan jika dibandingkan dengan nilai jual jenis ikan lain maka ikan jenis inilah yang paling rendah nilainya. Hal ini merupakan salah satu kendala bagi nelayan penangkap ikan tembang. Olahannya pun masih sederhana, terbatas pada penggaraman dan pengeringan. Ada bermacam-macam pengolahan ikan yang dapat dilakukan untuk meningkatkan nilai jual hasil perikanan, antara lain dengan cara: pembuatan abon ikan, tepung bumbu instan, tepung untuk pakan ternak, minyak ikan, kecap ikan, silase ikanikan kaleng dan lain sebagainya. Pembuatan beberapa produk hasil olahan perikanan dengan menggunakan berbagai metode dapat dilakukan oleh masyarakat sebagai kegiatan home industri.

Penelitian ini bertujuan untuk menemukan metode praktis pengolahanikan tembang menjadi beberapa produk makanan yang bertaraf home industri dan memiliki nilai ekonomi tinggi dan daya awet relatif lama berupa kecap ikan, ikan kaleng dan Silase ikan (bubur ikan). Hasil penelitian ini diharapkan dapat menjadi pengetahuan dasar masyarakat dalam rangka meningkatkan nilai jual ikan tembang sebagai produk perikanan yang bernilai ekonomi tinggi yang selanjutnya dapat meningkatkan taraf hidup masyarakat nelayan.

\section{METODE PENELITIAN}

Penelitian ini dilaksanakan bulan Maret s/d Desember 2018 di Laboratorium Biologi Terpadu Fakultas Perikanan dan Ilmu Kelautan UMI, Laboratorium Biofarmaka PKP UNHAS, Laboratorium Pakan Ternak Fakultas Peternakan UNHAS, Laboratorium Balai Besar Industri Perkebunan dan Perdagangan Makassar.

Perlakuan yang dilakukan dalam penelitian ini berupa: 
a. Kecap ikan

- Waktu inkubasi dan fermentasi (3 hari, 5 hari, 7 hari \& 9 hari)

- Konsentrasi pemberian garam ( $0 \%, 10 \%, 15 \%$ dan $20 \%$ )

b. Ikan Keleng

- Metode pemasakan (M1= kukus langsung, M2 = digoreng lalu dikukus)

- waktu pemasakan (T1 = 15 menit, $\mathrm{T} 2=30$ menit, $\mathrm{T} 3=45$ menit)

- Jenis bahan kemasan $(\mathrm{K}=$ plastik transfaran, $\mathrm{K} 2=$ plastik semi aluminium,K3 yakni pelastik berlapis aluminium)

c. Selase ikan

- pemberian jenis bakteri dari cacahan kubis

- penggunaan ragi tape sebagai bahan fermentasi

- Waktu fermentasi ( 3 hari, 5 hari, 7 hari)

- kandungan gizi kecap ikan, ikan kaleng dan selase ikan (karbo hidrat, lemak, protein, mineral, vitamin, serat, bahan toksit)

- kandungan mikroba, dan logam berat

- kualitas kecap ikandan ikan kaleng
- uji organoleptik, dan pengamatan daya awet (kecap ikan dan ikan kaleng)

- kualitas selase ikan

\subsection{Uji Organoleptik}

Uji Organoleptik adalah cara penilaian dengan hanya menggunakan indra manusia (sensorik). Penilaian organoleptik merupakan cara yang paling banyak dilakukan dalam menentukan tanda-tanda kesegaran bahan makanan termasuk ikan, karena lebih cepat, tidak memerlukan banyak peralatan serta murah. Uji organoleptik untuk ikan dapat dilakukan denganmenggunakan lembar penilaian (score sheet) yang sudah ditetapkan oleh Badan SNI (SNI-01-2346-2006), meliputi penampakan luar, kelenturan daging (konsistensi) daging, cita rasa, aroma serta warna.

\subsection{Analisis Data}

Untuk analisis laboratorium (analisis kandungan gizi, mikroba dan bahan toksit). Disamping itu juga data yang diperoleh secara kualitatif diolah dengan cara deskriptif serta data yang diperoleh secara kuantitatif yang diperoleh dari data pengamatan laboratorium dan uji organoleptik dilakukan dengan analisis ragam 
(rancangan acak lengkap) dengan tiga kali ulangan.

HASIL DAN PEMBAHASAN

A. Kecap Ikan

1. Kandungan Gizi

Hasil analisis kandungan gizi dari kecap dengan perlakuan pemberian garam saat fermentasi dapat dilihat pada Tabel 1.

\section{Analisis Kandungan Gizi Kecap}

\section{Ikan Tembang}

Tabel 1. Hasil analisis kandungan gizi kecap ikan tembang dengan perlakuan perbedaan konsentrasi garam

\begin{tabular}{|c|c|c|c|c|c|}
\hline \multirow{2}{*}{ perlakuan } & \multicolumn{6}{|c|}{ Parameter } \\
\cline { 2 - 6 } & Karbohidrat & Lemak & Protein & Abu & Air \\
\hline Perlakuan 1 (0\%0) & 36.73 & 1.82 & 0.69 & 2.56 & 27.9 \\
\hline Perlakuan 2 (10\%) & 38.22 & 1.08 & 0.88 & 6.54 & 22.79 \\
\hline Perlakuan 3 (15\%) & 39.39 & 1.36 & 3.15 & 7 & 24.66 \\
\hline Perlakuan 4 (20\%) & 25.38 & 3.37 & 2.64 & 9.74 & 16.47 \\
\hline Pembanding & 3.6 & 0 & 5 & 7.8 & 15 \\
\hline Dari hasil pengamatan & kecap pembanding kecuali pada
\end{tabular}

secara umum dapat dikatakan bahwa

kandungan karbohidrat, lemak dan air umumnya dari empat perlakuan lebih tinggi disbanding dengan kandungan protein, lemak dan air dari keap $\mathrm{ABC}$ sebagai sampel pembanding akan tetapi kandungan protein dan abu keempat perlakuan lebih rendah dibanding kandungan protein dan abu perlakuan $20 \%$ garam menunjukkan kandungan abu lebih tinggi dibanding kandungan abu kecap $\mathrm{ABC}$ sebagai pembanding. Hal ini dapat dilihat pada Gambar 2. Adapun analisis sidik ragam masing-masing parameter untukut melihat pengaruh perlakuan dilakuan dengan rancangan acak lengkap (RAL): 


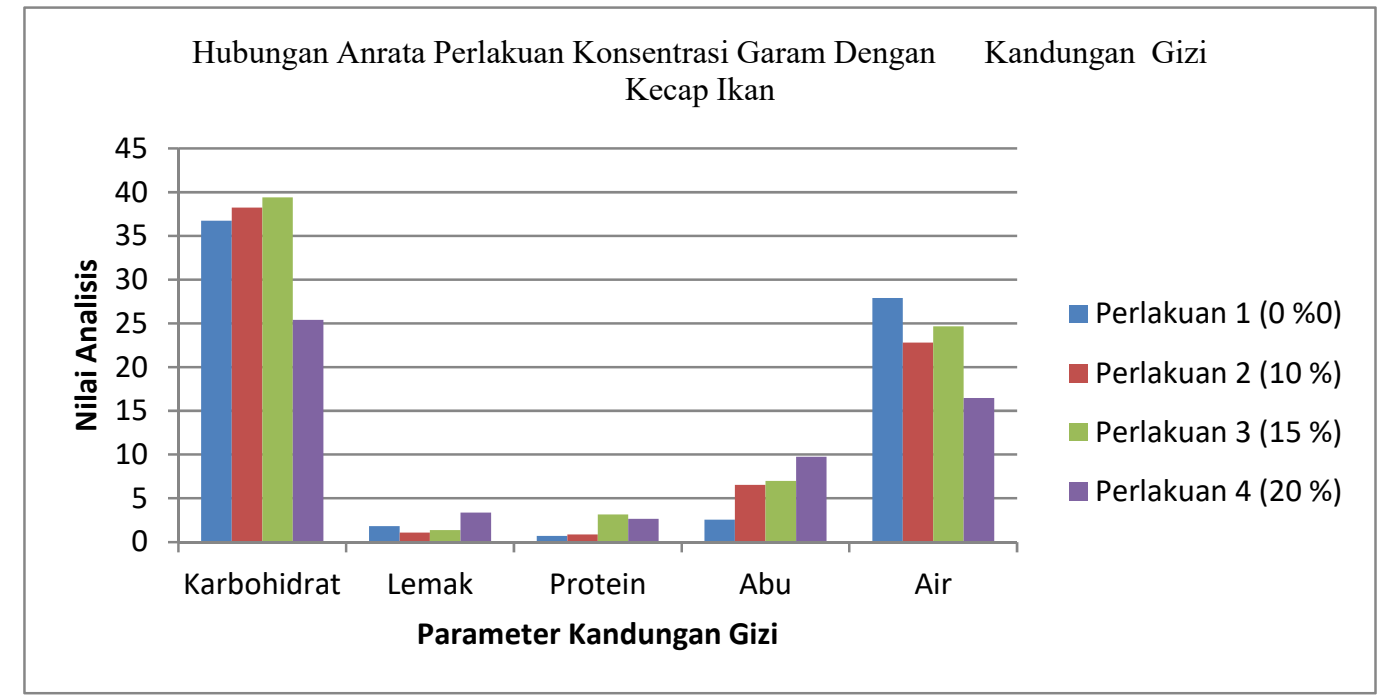

Gambar 2. Hubungan Anrata Perlakuan Konsentrasi Garam dengan Kandungan Gizi Kecap Ikan

\section{Kandungan Karbohidrat Kecap}

\section{Ikan Tembang}

Berdasarkan hasil analisis sidik ragam penelitian yang dilakukan terhadap kadar karbohidrat kecap ikan menunjukkan bahwa antara satu perlakuan dengan perlakuan lainnya yaitu dengan pemberian garam $0 \%$, $10 \%, 15 \%$ dan $20 \%$ masing-masing berbeda nyata. Selanjutnya berdasarkan hasil uji BNJ maka nampak bahwa dengan pemberian garam pada peroses pembuatan kecap ikan memberi pengaruh terhadap kadar karbohidrat pada kecap ikan. Hal ini memberi indikasi bahwa dengan adanya larutan $\mathrm{NaCl}$ dapat merombak karbohidrat dalam daging ikan secara maksimal, yang ditunjukkan bahwa dengan pemberian konsentrasi tertinggi dalam penelitian ini $(15 \%)$ dapat menghasilkan 39.39 gr karbohidrat, yang merupakan perlakuan yang paling banyak menghasilkan karbohidrat terlarut dalam kecap. Dari hasil penelitian menunjukkan bahwa perlakuan $20 \%$ adallah perlakuan yang paling kurang menghasilkan karbohidrat (25.38 gr) kemudian perlakuan $0 \%$ yiatu $(36.63$ gr) menyusul perlakuan $10 \%$ yaitu (38.22 gr) dan tertinggi adalah perlakuan $15 \%$ dengan jumlah karbohidrat (39.39\%). 
Dari hasil penelitian ini dengan perlakuan pemberian garam pada proses fermentasi jika dibandingkan dengan kandungan karbohidrat kecap ABC sebagai bahan pembanding dengan kandungan kafrbohidrat 3.6 gr maka dapat dikatakan bahwa kecap hasil penelitian ini mengandung karbohidrat diatas kandungan karbohidrat kecap ABC.

\section{Lemak Kecap Ikan Tembang}

Analisis sidik ragam hasil penelitian menunjukkan kandungan lemak kecap ikan sangat berfariasi dari yang terendah ke yang tertinggi yaitu perlakuan $10 \%$ (1.08 gr) kemundian perlakuan $15 \%$ (1.36 gr) kemudian perlkuan $0 \%\left(\begin{array}{llll}1.82 & \text { gr }\end{array}\right)$ dan yang tertinggi adalah control $20 \%$ (3.37). hal ini menunjukkan bahwa dengan pemberian garam $\mathrm{NaCl}$ pada konsentrasi tinggi sampai $20 \%$ dapat memberi reaksi pelepasan ion lemak dari daging ikan yang selanjutnya terlarut dalam larutan kecap. Hasil analisis kandungan lemak pada beberapa perlakuan pembuatan kecap ikan dalam penelitian ini, memperlihatkan perbedaan yang nyata bahkan umumnya lebih tinggi dari kandungan lemak yang terdapat pada kecap ABC sebagai bahan pembanding menurut (Bucle, 1985).

Berdasarkan analisis sidik ragam hasil penelitian menunjukkan adanya perbedaan nyata antara perlakuan, dan dengan uji BNJ dari beberapa perlakuan dalam penelitian ini. Hal ini menunjukkan bahwa antara perlakuan $0 \%$, perlkuan $10 \%$, perlakuan $15 \%$ dan perlakuan $20 \%$ masing-masing memberi pengaruh yang nayata, akan tetapi yang paling pesar pengaruhnya terhadap pelepasan lemak dari akuan $20 \%$ (3.337 gr).

\section{Protein Kecap Ikan Tembang}

Kandungan protein kecap ikan dalam penelitian ini sangat berfariasi dari yang terendah pada perlakuan control (0 \%) yaitu 0.69 gr salanjutnya perlakuan $10 \%,(0.88 \mathrm{gr})$ kemudian perlakuan $20 \%$ (2.64 gr) dan paling tinggi dicapai pada perlakuan $15 \%$ (3.15 gr). Pemberian garam pada batas $15 \%$ dapat meningkatkan reaksi katalisis untuk mengurai ion protein dalam daging ikan terurai kedalam larutan kecap. Namun demikian jika dibandingkan dengan produk kecap ABC sebagai bahan pembanding maka dapat dikatakan bahwa kandungan 
protein kecap $\mathrm{ABC}$ lebih tinggi (5 gr) Bucle., 1985.

Berdasarkan analisis BNJ menunjukkan bahwa perlakuan $0 \%$ (control) dan perlakuan $10 \%$ memiliki pengaruh yang sama ( $\alpha$ tidak berbeda nyata), demikian juga halnya antara perlakuan $\quad 15 \quad \% \quad$ dan $20 \quad \%$ memperlihatkan perbedaan tindak nyata dengan kata lain antara dua perlakuan memiliki pengaruh yang sama terhadap kandungan protein kecap ikan. Akan tetapi antara perlakuan 1 \& 2 berbeda mhyata terhadap perlakuan $3 \& 4$. Hal ini memberi informasi kepada kita bahwa pembuatan kecap ikan dengan pemberian garam saat fermentasi maksimum pada konsentrasi $15 \%$ sebab jika lebih besar dari itu justru dapat menurunkan kembali kandungan protein kecap ikan.

\section{Kadar Abu Kecap Ikan Tembang}

Kadar kandungan abu atau serat kecap ikan dalam penelitian ini dengan perlakuan pemberian beberapa konsentrasi garam saat fermentasi berdasarkan analisis sidik ragan menunjukkan perbedaan nyata sehingga dapat dikatakan bahwa dengan beberapa perlakuan pemberian garam pada proses pembuatan kecap ikan tembang dalam penelitian ini memberi pengaruh terhadap kandungan abu kecap ikan. Hal ini ditunjukkan dengan nilai $\mathrm{F}$ hitung $(180.27>\alpha)$. Berdasarkan uji BNJ menunjukkan bahwa perlakuan 2 dan 3 tidak berbeda namun berbeda dengan perlakuan 1 dan perlakuan 4sehingga dapat dikatakan bahwa perlakuan penggaraman dalam pembuatan kecap ikan sangat besar pengaruhnya.

Hasil pengamatan menunjukkan bahwa diantara empat jenis perlakuan memperlihatkan kandungan abu terendah dihasilkan oleh perlakuan $0 \%$ (2.56) selanjutnya perlakuan $10 \%$ (6.54) disusul perlakuan $15 \%$ (7.0) dan tertinggi pada perlakuan $20 \%$ (9.74). Hal ini menunjukkan bahwa semakin tinggi konsentrasi pemberian garam menunjukkan semakin tingginya kadar endapan abu dalam kecap. Hal ini dimungkinkan dengan adanya tambahan $\mathrm{NaCl}$ menyebabkan reaksi yang dapat menarik ion-ion mineral dalam daging ikan.

\section{Uji Organoleptik Kecap Ikan} Tembang

Uji pedogenik (organoleptic) kecap ikan hasil penelitian 
membandingkan antara beberapa perlakuan serta dengan kecap produksi lain yaitu kecap $\mathrm{ABC}$ produk $\mathrm{PT}$. Indofooddengan mengamati beberapa sifat pedogenik kecap antara lain
Warna, Aroma, Rasa dan Tekstur. Secara umum hasil pengamatan uji organoleptik yang dilakukan oleh beberapa panelis pada saat awal produksi dapat dilihat dalam Tabel 2.

Tabel 2. Hasil uji Organoleptik Kecap Ikan Sakp-rat Pengamatan Awal

\begin{tabular}{|l|c|c|c|c|}
\hline perlakuan & Warna & Rasa & Aroma & Tekstur \\
\hline Perlakuan 1 (0\%) & 2 & 2 & 2 & 1.5 \\
\hline Perlakuan 2 (10 \%) & 2 & 3 & 2.5 & 2.5 \\
\hline Perlakuan 3 (15\%) & 1.5 & 4 & 3 & 4 \\
\hline Perlakuan 4 (20 \%) & 3 & 3 & 2.5 & 3 \\
\hline Kecap Pembanding & 4 & 3 & 3 & 3.5 \\
\hline \multicolumn{5}{r}{ (kecap ABC) dengan nilai }
\end{tabular}

\section{Warna Kecap Ikan Tembang}

Hasil uji organoleptic nilai warna kecap ikan (Tabel 4), menunjukkan bahwa nilai warna kecap ikan pada perlakuan $3(15 \%)$ yaitu nilai organoleptik 3 dengan warna coklat kemerah-merahan dan Nampak bersih dan penampakan warna yang paling rendah atau nilai organoleptic terendah ditunjukkan pada perlakuan $20 \%$ dengan nilai uji 1.5 yaitu warna merah tua agak buram. Hal ini menunjukkan bahwa pemberian garam pada kecap ikan tembang maksimal 15 $\%$ sehingga pemberian yang lebih besar dari itu dapat berefek pada penampakan warna yang lebih gelap dan buram. Warna kecap dengan perlakuan pemberian garam jika dibandingkan sampel pembanding organoleptik 4 (warna agak gelap) maka dapat dikatakan bahwa warna kecap ikan tembang lebih cerah dan Nampak lebih jernih. Selanjutnya jika dibandingkan dengan warna kecap ikan hasil penelitian (Kristianawati, dkk., 2014). menghasilkan warna kecap kemerah-merahan sampai buram akibat bahan baku yang menggunakan hati ikan, selanjutnya dikatak diduga hati memberi kontribusi terhadap warna merah dan coklat pada kecap ikan karena mengandung banyak butir-butir darah merah atau hemoglobin. Warna kecap ikan terbentuk bertahap selama fermentasi.

Semakin besar kadar garam yang ditambahkan maka warna akan menjadi bergeser dari merah kearah colklat sampai batas $15 \%$ dan pada 
konsentrai $20 \quad \% \quad$ kecerahannya berkurang hingga agak buram. Klomklao et.al. (2005), menyatakan bahwa semakin tinggi kadar garam yang digunakan pada proses pembuatan kecap ikan maka akan menaikkan intensitas warna produk.Tingkat perubahan warna yang terbentuk diantara perlakuan bervariasi, tergantung pada perbedaan konsentrasi garam yang ditambahkan. Hal ini mengindikasikan bahwa dengan adanya perbedaan konsentrasi garam memberikan pengaruh terhadap pembentukan warna pada kecap ikan. Perlakuan konsentrasi $15 \%$ menunjukkan warna yang lebih cerah dibanding perlakuan dengan $0 \%$, dan $10 \%$ menyebabkan warna kecap coklat mudah, sementara dengan $20 \%$ warnanya buram. Hal tersebut dikarenakan warna yang dihasilkan menyerupai dengan warna kecap ikan komersial yaitu coklat. Selain itu lama proses fermentasi juga menentukan warna kecap

Warna kecoklatan yang terbentuk pada kecap ikan diduga disebabkan oleh reaksi non enzimatis yaitu reaksi Maillard. Lopetcharat et.al., (2001), mengungkapkan bahwa Reaksi Maillard mungkin berkontribusi pada kecenderungan warna merah. Gula pereduksi dan produk oksidasi seperti aldehid dapat bereaksi dengan asam amino bebas yang lebih banyak dibebaskan dengan semakin bertambahnya waktu fermentasi. Ginting (2002), menambahkan bahwa semakin lama berlangsungnya proses fermentasi, warna kecap semakin keruh karena semakin banyaknya komponenkomponen yang terdapat pada cairan hasil fermentasi sehingga cairan semakin pekat dan semakin keruh.

\section{Aroma Kecap Ikan Tembang}

Aroma yang dihasilkan pada perlakuan kontrol lebih menyengat dibandingkan dengan perlakuan lainnya. Aroma yang terbentuk pada kecap ikan Tembang sangat dipengaruhi dari aroma khas bahan baku, sehingga aroma yang dihasilkan berbeda dengan kecap ikan komersial sebagai pembandingnya yang umumnya terbuat dari ikanikan kecil pelagis ukuran kecil. Menurut Shimoda et al., (1996), Fukami et al., (2004) dalam Yongsawatdigul et al., (2004) variasi senyawa volatil, asam yang terkandung, karbonil, kandungan 
senyawa nitrogen dan senyawa sulfur yang terbentuk selama proses fermentasi diduga mempengaruhi pembentukan aroma yang berbeda pada kecap ikan. Aroma condiment dapat berasal dari adanya senyawasenyawa volatil yang mempunyai berat molekul rendah yaitu asam-asam organik dan karbonil. Hasil penerimaan panelis nilai rasa kecap ikan Tembang perlakuan dengan konsentrasi garam $15 \%$ lebih tinggi dibanding dengan nilai rasa perlakuan yang lain. Menurut Buckle et al., (1987), garam mampu menguraikan protein menjadi beberapa komponen seperti peptida, pepton dan asam amino yang saling berinteraksi menciptakan rasa yang khas. Rahayu et al., (1992) yang mengemukakan bahwa proses fermentasi yang terjadi pada ikan merupakan proses penguraian secara biologis terhadap senyawasenyawa yang lebih sederhana dan terkontrol. Selama proses fermentasi, protein ikan akan terhidrolisis menjadi asam amino dan peptida, kemudian asam-asam amino akan terurai lebih lanjut menjadi komponen-komponen lain yang berperan dalam pembentukan cita rasa produk. Selanjutnya dikatakan bahwa degradasi protein ikan menjadi asam amino bebas merupakan penyebab dari pembentukan cita rasa yang enak pada kecap ikan.

Hasil uji organoleptik penerimaan keseluruhan produk kecap ikan tembang yang tersaji pada Gambar 2, dapat diketahui bahwa nilai organoleptik penerimaan keseluruhan produk berada pada kisaran 2.5 (agak menyengat) sampai 4 (sangat harum).

\section{Rasa Kecap Ikan Tembang}

Uji organoleptik yang dilakukan terhadap cita rasa, dengan jumlah panelis 10 orang dengan menggunakan metoda New Duncan Multiple Range Test dikarenakan sederhana dalam perhitungan, jumlah panelis $<20$ orang, dapat dibandingkan dengan produk kontrol sehingga dapat diperkirakan produk yang diuji dapat nilai suka hingga sangat suka dengan metoda ini dapat diketahui tingkat kepercayaannya. Metoda New Duncan Multiple Range Test ini pembandingakan nilai ratio dari tiap kelompoknya denga nilai total. Tingkat kepercayaan yang digunakan dalam uji organoleptik ini $\alpha=0.5$ 
Dari perhitungan Metoda New Duncan Multiple Range Test maka dapat diklasifikasikan uji organoleptik berdasarkan nilai rata-rata para panelis, berdasarkan distribusi $\mathrm{t}$ dan nilai uji yang diperoleh dari tiap kelompok terhadap total nilai uji sesuai hasil pengamatan. Berdasarkan nilai rata-rata uji organoleptik dengan metoda New Duncan Multiple Range Test terhasap cita rasa, nilai yang cukup besar disukai oleh para panelis yaitu cita rasa pada nilai 4 dengan kadar protein 3,15\% dengan rasa khas ikan hal ini diperoleh pada perlakuan $15 \%$. Pada konsentrasi larutan garam yang semakin besar dari itu diperoleh semakin keruh kecoklatan karena banyaknya endapan yang dihasilkan serta rasa yang agak amis.

Hasil uji organoleptik tersebut dapat di lihat padaTabel 4.Berdasarkan uji organoleptik distribusi $t$, nilai $t$ yang dihitung dengan metoda New Duncan Multiple Range Test yang kemudian dibandingkan dengan nilai $t$ dari tabel distribusi t dengan nilai $15 \%$ dengan $\alpha=0.50$, nilai $\mathrm{t}$ dari cita rasa dapat diterima, hal ini dikarenakan para panelis lebih menyukai kecap ikan dengan pemberian garam $15 \%$ saat fermentasi dari hasil penelitian dibandingkan dengan kecap pembanding yang diperoleh dari pesaran karena aroma kecap dari hasil penelitian beraroma ikan khas.

Berdasarkan uji organoleptik dengan metoda New Duncan Multiple Range Test menyatakan bahwa setiap citarasa, pada masingmasing variasi perlakuan berbeda. Cita rasa pada fermentasi dengan konsentrasi $0 \%$ dan $10 \%$ tidak berbeda namun akan berbeda dengan agan perlakuan $15 \%$ dan $20 \%$.

\section{Tekstur Kecap Ikan}

Uji organoleptik tekstur kecap ikan tembang merupakan uji penampakan dan kekentalan kecap hasil penelitian memperlihatkan kenampakan yang cukup baik jika dibandingkan dengan kecap $\mathrm{ABC}$ sebagai pembanding. Hasil uji tekstur kecap ikan pada beberapa perlakuan menunjukkan perbedaan yang nyata antara satu perlakuan dengan perlakuan lainnya. Pada perlakuan 0 $\%$ dan $10 \%$ tidak berbeda akan tetapi berbeda dengan perlakuan $15 \%$ dan 20 $\%$.

Hasil pengamatan juga menunjukkan bahwa nilai organoleptik 
dengan perlakuan kontrol ( $\left.\begin{array}{ll}0 & \%\end{array}\right)$ memperlihatkan penampakan tekstur yang terendah, hal ini memberi informasi kepada kita bahwa penggunaan garam pada fermentasi pembuatan kecap ikan tembang sangat berpengaruh dan memberi nilai tambah terlihat bahwa tanpa garam kecap yang dihasilkan cenderung encer dan penampakan kurang stabil.
Akan tetapi dengan pemberian garam yang berlebih melebihi konsentrasi 15 $\%$ menyebabkan nampaknya endapan yang agak kasar dan menurunkan nilai struktur kecap.Hasil pengamatan nilai organoleptik warna, rasa, aroma dan tekstur dalam hubungannya dengan perlakuan dapat dilihat pada Gambar 6.

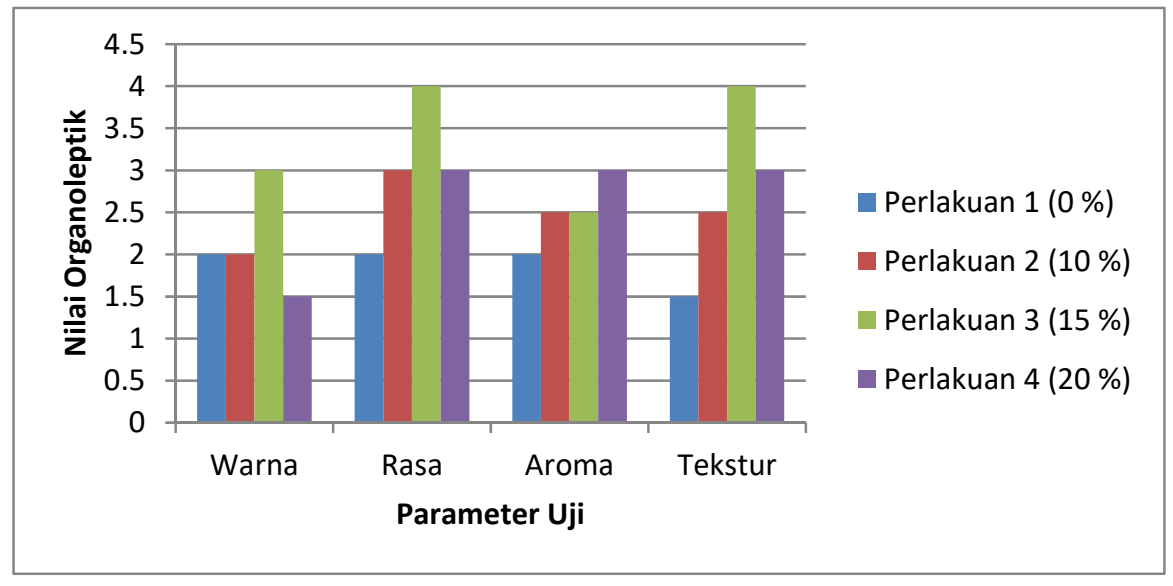

Gambar 2. Hubungan Antara Perlakuan Penggatraman dengan Sifat Organolepgtik Kecap Ikan

Hasil produksi kecap ikan Penampakan hasil produksi kecap ikan tembang yang diperoleh dalam tembang dalam penelitian ini dapat peneltian ini jika dibandingkan dengan dilihat pada Gambar 3.

beberapa jeis produksi kecap yang beredar di pasaran baik dari segi kandungan gizi maupun dari kualitas organoleptiknya berupa aroma, rasa, warna dan tekstur tidak jauh berbeda.

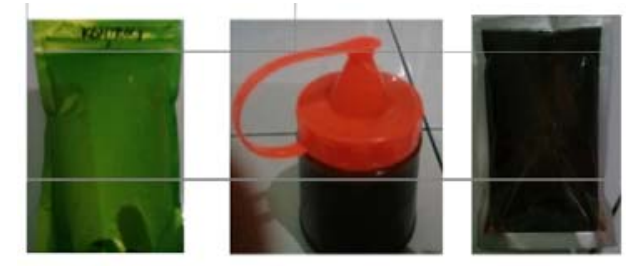

Gambar 3. Hasil Produk Kecap Ikan 
B. Ikan Kaleng

\section{Kandungan Gizi Ikan Kaleng \\ Protein Ikan Kaleng}

Berdasarkan hasil penelitian ini menunjukkan bahwa perlakuan pemasakan dengan kukus langsung dengan pemasakan 15 menit (M1T1) mengandung protein paling rendah (14.65) diantara semua perlakuan, sementara pada perlakuan pemanasan bertingkat dengan diawali penggorengan lalu dikukus (MT2) memperlihatkan kandungan protein tertinggi (21.5), akan tetapi dari semua perlakuan bardasarkan analisis sidik ragam memperlihatkan perbedaan yang nyata hal ini mengindikasikan bahwa dengan perlakuan metode pemasakan dan suhu mempengaruhi kandungan protein pada ikan kaleng.

Dari uji BNT menunjukkan bahwa pada perlakuan M1T1 berbeda dengan perlakuan M1T2, M1T3 berbeda dengan M2T1, demikian juga perlakuan M2T2, M2T3. Namun untuk perlakuan M1T2 dan M1T3 sama serta perlakuan M2T2 dan M2T3 sama. Hal ini menunjukkan bahwa perlakuan kukus langsung dengan pemasakan 30 menit dan 45 menit tidak berpengaruh demikian juga perlakuan pemasakan dengan penggotengan + kukus dengan waktu pemasakan 30 menit dan 45 menit relative sama dan tidak berbeda nyata kandungan proteinnya yaitu memiliki kandungan protein tertinggi. Dari pengamatan ini dapat dikatakan bahwa untuk menapatkan kandungan protein tertinggi pada ikan kaleng tembang dapat dengan pemasakan bertingkat yang diawali dengan penggorengan dengan waktu pemasakan $30-45$ menit.

\section{Lemak Ikan Kaleng}

Hasil pengamatan kandungan lemak ikan kaleng dalam penelitian ini menunjukkan bahwa berdasarkan analisis sidik ragam bahwa kandungan lemak pada beberapa perlakuan dalam penelitian ini berbeda nyata sehingga dapat dikatakan bahwa diantara beberapa jenis perlakuan terdapat pengaruh yang nyata sehingga dapat dikatakan perlakuan metode pemasakan dan suhu dapat memberi pengaruh terhadap kandungan lemak ikan kaleng. Dari hasil penelitian perlakuan pemasakan dengan metode kukus langsung dengan suhu $15^{\circ} \mathrm{C}$ (M1T1) memiliki kandungan lemak yang paling rendah (1.65), sementara perlakuan pemasahan kukus yang diawali dengan penggorengan dengan 
suhu $30^{\circ} \mathrm{C}$ memiliki kandungan lemak tertinggi (3.57). Analisis sidik ragam perlakuan menunjukkan bahwa hasilnya berbeda nyata sehingga dapat dikatakan metode pemasakan berpengaruh terhadap kandungan lemak ikan kaleng.

$$
\text { Berdasarkan uji BNT }
$$
memperlihatkan bahwa perlakuan M1T1 berbeda dengan perlakuan M1T2, M1T3, M2T1, M2T3 dan berbeda dengan M2T2.Akan tetapi perlakuan M1T2, 1T3, M2T1, M2T3 masing-masing tidak berbeda sahingga dapat dikatakan bahwa perlakuan yang lebih dominan mempengaruhi kandungan lemak adalah metode pemasakan yang ditunjukan bahwa pemasakan kukus dengan diawali penggorengan sebelumnya memiliki pengaruh yang nyata terhadap kandungan lemak ikan kaleng. Hal ini dimungkinkan terjadinya penguraian lemak ikan saat penggorengan sehingga lemak yang terkandung dalam ikan dapat terurai lebih sempurna disbanding dengan tanpa penggorengan. Selain itu Nampak juga dalam penelitian ini adanya pengaruh suhu yang ditunjukkan bahwa dengan pemasakan 300C dapat mengurai lemak ikan lebih banyak disbanding dengan suhu $15^{\circ} \mathrm{C}$ dan $45^{\circ} \mathrm{C}$.

\section{Karbohidrat Ikan Kaleng}

Berdasarkan uji BNT hasil penelitian dapat dikatakan bahwa antara perlakuan M1T2 dan M1T3 tidak berbeda, demikian juga antata perlakuan M1T1 dan M2T1 tidak berbeda, sertaantara perlakuan M2T2 dan M2T3 tidak berbeda nyata, akan tetapi perlakuan M1T1, MT3 berbeda dengan perlakuan M1T1, M2T1 dan berbeda dengan perakuan M2T2, M2T3. Dari pola perbedaaan pengaruh perlakuan terhadap kandungan karbohidrat ikan kaleng dalam penelitian ini memperlihatkan bahwa metode pemasakan lebih besar pengaruhnya jika dibanding dengan perlakuan suhu pemasakan bahkan pada perlakuan penggorengan dan kukus pada suhu $30^{\circ} \mathrm{C}$ terjadi perombakan dan penguraian karbohidrat secara maksimal disbanding dengan suhu $15^{\circ} \mathrm{C}$ dan suhu $45^{\circ} \mathrm{C}$.

\section{Kadar Abu Ikan Kaleng}

Berdasarkan uji BNT kandungan abu ikan kaleng tembang memperlihatkan bahwa terdapat kombinasi perlakuan berbeda nyata 
walaupun pada perlakuan M1T1, M1T2, M1T3, M2T1 relatif sama atau tidak berbeda nyata yang artinya bahwa perlakuan perlakuan kukus dengan beberapa fariasi suhu tidak mempengaruhi perubahan jumlah kandungan abu pada ikan kaleng. Akan tetapi untuk perlakuan M2T2 dan M2T3 memberi pengaruh yang sama namun berbeda dengan perlakuan lainnya terhadap kandungan abu ikan kaleng, hal ini berarti bahwa metode pemasakan dengan cara goring dan kukus pada suhu $30^{\circ} \mathrm{C}$ dan $45^{\circ} \mathrm{C}$ memberi pengaruh yang nyata disbanding perlakuan lain, dapat dilihat dari hasil analisi Laboratrium

\section{Uji Organoleptik Ikan Kaleng}

\section{Perubahan Rasa Ikan Kaleng}

Uji oranoleptik pekan pertama pada semua perlakuan ikan kaleng menunjukkan bahwa dari keempat kriteria parameter uji terlihat bahwa pada perlakuan penggorengan dan pengukusan dengan suhu pemasakan 300C, cenderung lebih baik (dengan nilai uji tertinggi) di banding dengan perlakuan lainnya sehingga dapat dikatakan bahwa dengan penggorengan disertai pengukusan untk perlakuan ini memiliki kandungan abu yang tinggi. Dengan demikian dapat dikatakan bahwa perombakan daging ikan tembang melepas kandungan abu dalam proses pembuatan ikan kaleng dapat cara maksimal pada metode penggorengan dan kukus dengan suhu $30^{\circ} \mathrm{C}-45^{\circ} \mathrm{C}$. Hasil produksi ikan kaleng dalam penelitian ini dapat dilihat pada Gambar 12.
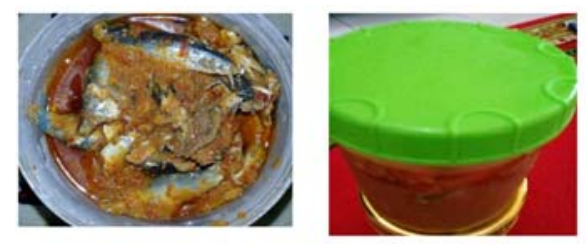

Gambar 4. Hasil Produk Ikan Kaleng

pada suhu 300C memberi efek warna cerah, aroma harum, rasas enak dan tekstur kompak, gambaran perbedaan hasil uji organoleptik dapat dilihat pada Gambar 5.

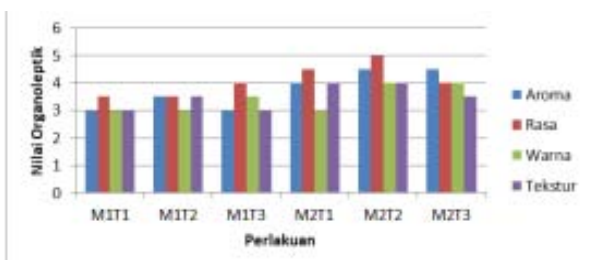

Gambar 5. Hasil Uji Organoleptik Pekan I Ikan Kaleng Semua Perlakuan 
Dari hasil uji organoleptik semua perlakuan maka ditetapkan satu perlakuan yaitu perlakuan M2T2 sebagai perlakuan yang terbaik untuk selanjutnya dijadikan sampel dikemas pada beberapa jenis kemasan dan disimpan pada suhu kamar untuk selanjutnya diamati perubahan sifat proksimatnya selama masa penyimpanan 14 pekan atau 3,5 bulan

\section{KESIMPULAN}

Dari hasil penelitian ini dapat dirumuskan beberapa kesimpulan antara lain:

1. Uji Peoksimat kandungan kecap ikan dengan pemberian garam jika dibandingkan dengan kecap pembanding (produk ABC) nilai gizinya relatif sama atau tidak terlalu jauh beda.

2. Kualitas kecap ikan dengan perlakuan penggaraman $15 \%$ lebih baik dibandingkan dengan perlakuan $0 \%, 10 \%$ dan $20 \%$. Hal ini ditunjukkan dengan uji organoleptik yang cenderung lebih baik sampai pada pengaatan terakhir.

3. Ikan kaleng dengan perlakuan penggorengan dilanjut dengan lamanya, yang diamati setiap selang dua pekan. Adapun jenis kemasan yang digunakan, antara lain: kemasan plastik transfaran (K1), kemasan plastik semi aluminium foil (K2), kemasan aluminium foil berlapis plastik (K3). Dari hasil analisis dan pengamatan uji organoleptik ikan kaleng tembang disajikan:

pengukusan dengan suhu $30^{\circ} \mathrm{C}$ memiliki kualitas yang lebih baik.

4. Kemasan yang peling baik dan dapat mempertahankan daya awet ikan kaleng diantara tiga perlakuan adalah kemasan aluminium berlapis pelatik

5. Selase ikan yang menggunakan tape ragi sebagai bahan fermentasi memperlihatkan kualits lebih baik dan cenderung tahan lama.

\section{SARAN}

Dari hasil penelitian ini dapat disarankan penelitian lanjutan tentang: Pengolahan minyak ikan dan bumbu ikan menjadi beberpa produk turunan yang bernilai ekonomi tinggi dan hasil penelitian ini selayaknya disosialisasikan kepada masyarakat dalam bentuk pengabdian masyarakat 
mengingat bahwa hasil penelitian ini mudah, aplikatif, bernilai ekonomi tinggi dan dapat diolah secara home industry.

\section{UCAPAN TERIMA KASIH}

Tulisan ini merupakan bagian dari penelitian dasar unggulan perguruan tinggi dan penulis mengucapkan terima kasih kepada Direktorat Riset dan Pengabdian Masyarakat, Direktorat Jenderal Penguatan Riset dan Pengembangan Kemnterian Riset, Teknologi dan Pendidikan Tinggi yang telah membiayai penelitian ini pada tahun anggaran 2018 .

\section{DAFTAR PUSTAKA}

Badan SNI (SNI-01-2346-2006), 2016. Petunjuk Pengujian Organoleptik Dan Atau Sensori

Bucle, K.A. 1985. Ilmu Pangan. Penerjemah Hari Purnomo, Adiono. UI Press. Jakarta

Kristianawati. F., Ibrahim R., Laras Rianingsih.,2014. penambahan enzim yang berbeda pada pengolahan kecap

ikan dari isi rongga perut ikan Manyung (arius thalassinus) terhadap mutu produk

Ginting, E. M. 2002.Pengaruh Aktifitas Manusia Terhadap Kualitas Air DiPerairan
Parapat Danau Toba. Medan:USU e-Repository.

Hariyadi, R.D. 2000. Sanitasi Industri Pengalengan Makanan. Di DalamHariyadi,P.,editor:

Dasar-dasar Teori dan Praktek Proses Termal. PusatStudi Pangan dan Gizi IPB. Bogor

Klomklao et.al. (2005), Digestive proteinases from marine organisms and their applications.

Department of Food Science and Technology, Faculty of Technology and Community Development, Thaksin University, Phattalung Campus, Phattalung, 93110, Thailand

Lopetcharat., 2001. 79-82. For Umami, see especially Kawamura and Karee ds. 1097., and Yamaguchi and Ninomiya 1998, 123-138.

Rahayu, P. W. 1992. Teknologi Fermentasi Produk Perikanan. Departemen Pendidikan dan Kebudayaan. Direktorat Jenderal Pendidikan Tinggi. Pusat Antar Universitas Pangan dan Gizi. IPB. Bogor. Yongsawatdigul., 2004. Biogenic Amines Formation in Fish Sauce Prepared from Fresh and Temperature-abused Indian Anchovy (Stolephorus indicus). Jurnal of Food Science 69(4):FCT312 - FCT319· May 2004 